\title{
Scholars and Literati at the Royal Bourbon College in Aix-en-Provence (1603-1763)
}

\author{
David de la Croix \\ IRES/LIDAM, UCLouvain
}

\author{
Alice Fabre \\ AMSE, Marseille
}

This note is a summary description of the set of scholars and literati who taught at the Royal Bourbon College in Aix-en-Provence (France) from its inception in 1603 to its disappearance, when Jesuits were expelled from Aix-en-Provence, and the College was absorbed into the old University of Aix in 1763.

\section{The UNIVERSITY}

The Royal Bourbon College (Collegium Regium Borbonium) was founded in 1603 by King Henry IV of France, who was the first of the Bourbon dynasty. The foundation of the College followed the request of the county's notables, who called for more resources for their university. The King went beyond their wishes, creating a new institution! During the first years of its existence (1603-1621), it was ruled by the secular clergy, and became a rival institution to the old University of Aix-en-Provence, founded in 1409. With the takeover of the College by the Jesuits in 1621, the royal professors in law, medicine, and theology moved to the old University of Aix. Under the Jesuits, the College served as the Faculty of Arts in Aix, the heir of the old grammar schools, but independent from the old University. When the Jesuits were expelled, the College was ruled by the secular clergy again, and was quickly absorbed by the University of Aix (suppressed in 1793, with the French Revolution). Following Frijhoff (1996), this note considers the Royal Bourbon College as a university from 1603 to 1763, focusing on the Jesuit period 1621-1763. The Royal Bourbon College seems to have been a pilot institution in France for the Jesuits, with the early introduction of lectures in French, in literature (poetry, theater, ...), and later in mathematics.

\section{SOURCES}

There is no catalogue of the professors of the Royal Bourbon College. The main source is Méchin (1890), who compiled a chronicle, based on the Jesuits' archives, about the life, the daily organization, and the governance of the Royal Bourbon College, in chronological order. This source allows us to harvest the names of the professors teaching at the College, with sparse bibliographic data. Additional information can be found in Belin (1905), who wrote on the history of the university of Aix, from its creation in 1409 to its abolishment in 1793. The volumes of the Bibliothèque de la Compagnie de Jésus by Carlos Sommervogel Sommervogel (1890) provide additional biographical information on the Jesuits who authored some work. The biographical dictionary of the county written by Paul Masson provides portraits of the individuals who were active in the county (Masson 1931). Finally, De la Croix and Fabre (2019) give a global analysis of the scholars at the two universities in Aix before 1793.

\section{SOME STATISTICS}

Table 1 shows some descriptive statistics. There are 185 scholars and literati. The year of birth is known for $58.9 \%$ of them, thanks to the information in Sommervogel (1890). The mean age at 
nomination is 38.5 years. Longevity (mean age at death \& expected age at death when 30 ) is relatively low, in particular during the last period (but computed on very small samples). The dissolution of the Society of Jesus and the French Revolution probably did not help them to lead a long and peaceful life. The birth place is known for only $65.9 \%$ of the individuals. The median distance between birth and Aix is $227 \mathrm{~km}$. This median varies considerably over time, with lower values at the beginning and at the end of the period considered. Given the size of the sample, this pattern should be interpreted with caution. Finally, $7.6 \%$ of the scholars have a Wikipedia page (in some language), and $28.6 \%$ of them have left a footprint in the catalogues of the libraries of the world, Worldcat, either by having published some work, or by having been the subject of published books and articles. These two percentages are to be seen as upper bounds, as the database is probably missing some of the obscure teachers of the College.

\begin{tabular}{|c|c|c|c|c|c|c|}
\hline \multicolumn{2}{|c|}{ Period } & $\mathrm{nb}$. & \% birth year & mean age & mean age & exp. age \\
\hline Start & End & obs & known & at nomin. & at death & at death \\
\hline 1527 & 1617 & 10 & 60 & 28 & 62.2 & 54.6 \\
\hline 1618 & 1685 & 85 & 52.9 & 38.7 & 66.7 & 65 \\
\hline 1686 & 1733 & 63 & 50.8 & 43.1 & 69.4 & 63.2 \\
\hline 1734 & 1800 & 27 & 96.3 & 33.4 & 62.2 & 59.9 \\
\hline 1200 & 1800 & $18 \overline{5}$ & $58 . \overline{9}$ & 38.5 & $\overline{6} \overline{6} . \overline{6}$ & 63.9 \\
\hline & & & $\begin{array}{c}\% \text { birth place } \\
\text { known }\end{array}$ & $\begin{array}{l}\text { median distance } \\
\text { birth-institution }\end{array}$ & $\begin{array}{c}\% \text { with } \\
\text { Wikipedia }\end{array}$ & $\begin{array}{c}\% \text { with } \\
\text { Worldcat }\end{array}$ \\
\hline 1527 & 1617 & & 70 & 70 & 30 & 60 \\
\hline 1618 & 1685 & & 60 & 227 & 5.9 & 25.9 \\
\hline 1686 & 1733 & & 60.3 & 253 & 4.8 & 22.2 \\
\hline 1734 & 1800 & & 96.3 & 123 & 11.1 & 40.7 \\
\hline 1000 & 1800 & & 65.9 & $22 \overline{7}$ & 7.6 & 28.6 \\
\hline
\end{tabular}

Table 1: Summary statistics by period

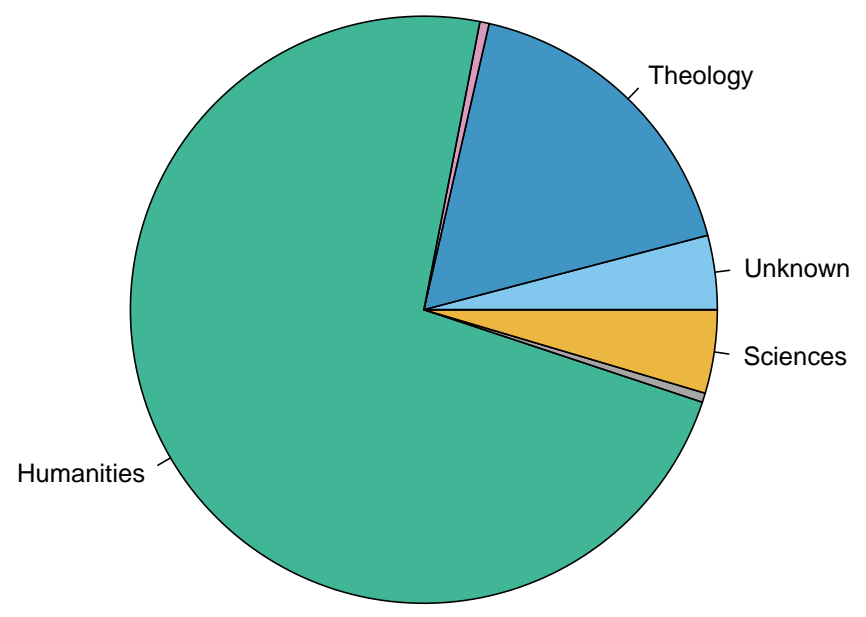

Figure 1: Broad fields at the Royal Bourbon College 


\section{FIELDS}

Figure 1 shows the relative importance of broadly defined fields. The university owed its reputation mainly to lectures in humanities (philosophy, rhetoric, literature, and poetry), but also in sciences, and theology. These figures reflect the vocation of the College to serve as a Faculty of Arts, contrary to "full" Jesuit Universities which also allowed for law and medicine studies, as in Pont-à-Mousson (De la Croix and Karioun 2021).

\section{Places of Birth}

Figure 2 is a plot of the places of birth of all the scholars of the Royal Bourbon College. The Rhone valley was the main basin of recruitment for the College. There was a strong Jesuit presence along this axis, with important colleges in Lyon and Avignon.

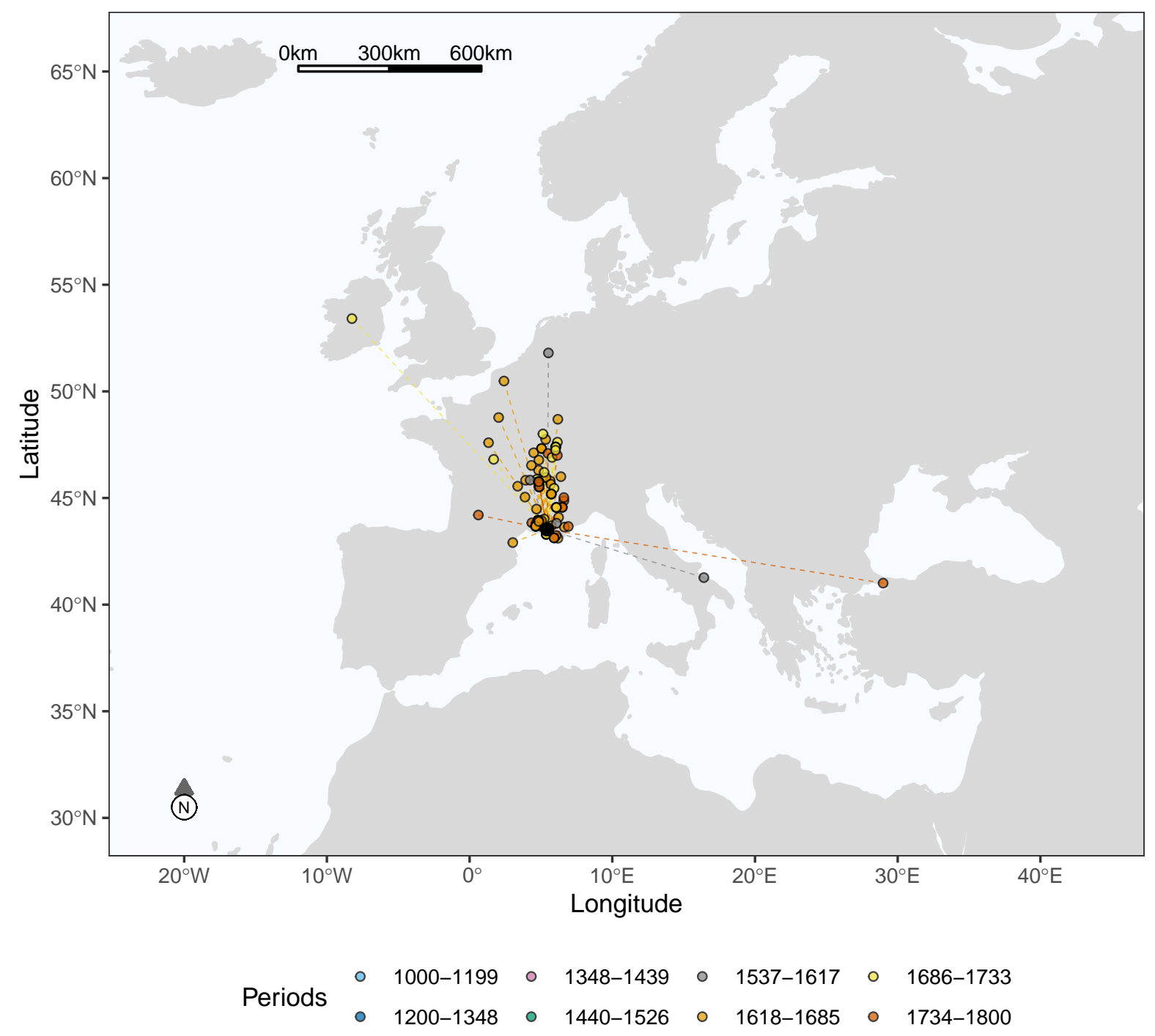

Figure 2: Places of birth of the scholars and literati at the Royal Bourbon College 


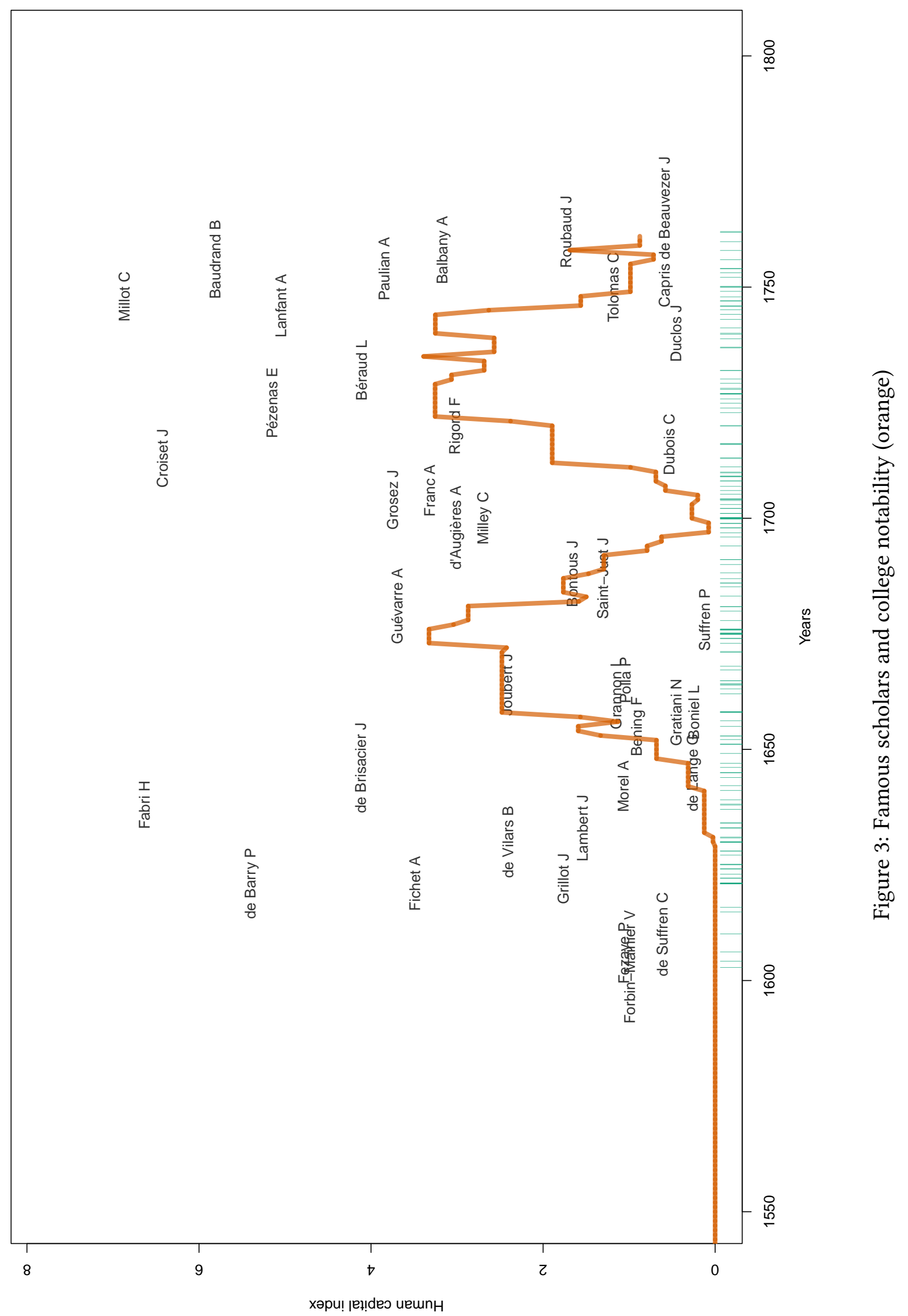




\section{HUMAN CAPITAL OF SCHOLARS AND LITERATI}

For each person in the database, we compute a heuristic human capital index, identified by combining information from Worldcat and Wikipedia using principal component analysis. We also compute the notability of the university at each date by averaging the human capital of the scholars active at the Royal Bourbon College 25 years before that date. Details are given in the Appendix. Figure 3 shows the names of all the scholars with a positive human capital index. The orange line plots the notability of the university.

The Royal Bourbon College experienced waves of medium to high notability, driven by some professors who published very well and were recognized, in some cases after their tenure at Aix. In general, Jesuit professors spend only a few years in the same place.

\section{TOP 7 PROFESSORS}

We now provide a brief overview of the seven professors with the highest human capital index.

Claude François-Xavier Millot (Ornans (Doubs) 1726 - Paris 1785) entered the Society of Jesus in 1641, teaching at many of their colleges, such as that in Aix in 1748, or in Lyon, where he taught rhetoric. In a speech, crowned by the Academy of Dijon in 1757, he praised Montesquieu, which displeased the Jesuit authorities; he left the order in 1759 and entered the secular clergy. A professor of history in Parma and tutor of the Duke of Enghien, he wrote important books on the history of France and England. A friend of philosophers, supported by d'Alembert, he was received into the Académie française (French Academy) in 1777.

Honoré Fabri (Virieu-le-Grand 1607 - Rome 1688) was a Jesuit who taught only one year in Aix, in 1638, where he became friends with Gassendi. During his career, he taught theology, philosophy, and sciences. On some occasions, he showed himself to be very orthodox in his interventions, trying for example to defend the point of view of the Church against Copernicus and Galileo (his nickname was "Devil's Advocate"), but was also sometimes seen as a precursor in science, and a vector of progress: his notoriety was linked to his lectures (including in Aix) on blood circulation, made apparently without knowing William Harvey's work on this subject. After Aix, he continued his career and experiments in Lyon and in Rome. It should be noted that his presence at the Royal Bourbon College is not mentioned in Méchin (1890) or in Sommervogel (1890), but in Callet (1909). His absence in Méchin (1890) might be related to the change of rector in 1638, leading to a gap in the records.

Jean Croiset (Marseille 1656 - Avignon 1738) was a professor of theology and the rector of the Royal Bourbon College in 1713. Before coming to Aix, he ruled the novitiate (for the training of future Jesuits) in Avignon for a long time. He is famous for his works on spiritual life, in particular for his book A spiritual retreat for one day in every month (1694). He raised money from the Jesuits' parish to renovate the college, and tried like his predecessors, unsuccessfully, to integrate the Royal Bourbon College into the old University of Aix.

Barthélémy Baudrand (Névache 1701 - Vienne (France) 1787) entered the Society of Jesus in 1721, and first taught letters and rhetoric. From 1756 to 1758, he was the spiritual director of the Royal Bourbon College, and then directed the College as its rector from September 1759 to 1761. He participated in the anti-Jansenist movement. In 1762, he was accused of having embezzled a noble lady of Aix-en-Provence, Mademoiselle de Villeneuve-Taoulet, taking advantage of his position as her confessor. The case was allegedly settled out of court. After the expulsion of the Jesuits from France, in 1763, he retired to Lyon, wrote and published spiritual works anonymously for the use of devout people. His works were translated into many languages.

Paul de Barry (Leucate 1587 - Avignon 1661) entered the Jesuit novitiate in 1605, and was the rector of the novitiates of Avignon, Chambéry, and Nîmes, and of the College of Aix (1631-1635). 
He composed several devotional works on the Blessed Virgin, St. Joseph, and the Saints, and a "Pensez-y-bien" (devotional exercises), which later had a large circulation and was translated into several languages.

Esprit Pezenas (Avignon 1692 - Avignon 1776) entered the Society of Jesus in 1709. He was a professor of philosophy and mathematics in Aix (1727). In 1729, he became a professor of hydrography in Marseille, where he developed the observatory; he equipped it with modern telescopes and published several books about seafarers' astronomy, while staying involved in the activities of the College. He retired in 1764 following the expulsion of the Jesuits, and returned to Avignon to continue his scientific and editorial activities there until his death. He was a member of several academies, like the Marine Academy of Brest (1752) and the Academy of Marseille (1776). In 1769, he became a corresponding member for the Royal Academy of Sciences in Paris.

Anne Alexandre Charles Marie Lanfant (Lyon 1726 - Paris 1792) entered the Society of Jesus in 1741, and taught philosophy and humanities in Aix in 1746. He read a poem about the solar eclipse at a college celebration. Later, he studied theology in Lyon (1751-1754) and became a preacher, in particular in Lorraine, when the Company of Jesus was suppressed, then in Vienna, at the court of Empress Maria Theresa. He returned to Paris and became a preacher at the court of Louis XVI, and from 1789 to 1791, the King's confessor. During the French Revolution, in September 1792, he was imprisoned. He refused to take an oath of loyalty to the Civil Constitution. He was recognized by the mob and executed.

\section{RELATED SCHOLARS}

Beyond those who taught at the Royal Bourbon College, several important individuals are related to the College. They probably did not occupy an official position there, but they were involved in preaching, teaching, and/or research, or there are strong assumptions that they were. Here, we show the three related scholars with the highest human capital index.

François d'Aix de la Chaise (Aix en Forez 1624 - Paris 1709) entered the Society of Jesus in 1649, and taught rhetoric, humanities, and philosophy in Lyon. He became the confessor of Louis XIV in 1675. Méchin (1890) relates multiple exchanges between the College and the King's confessor to successfully obtain the nomination of specific professors or preachers, or to (less successfully) help the College to have professors of theology become members of the University of Aix (in 1706 for instance).

Cornelius Jansen (Acquoy 1585 - Ypres 1638). As explained in De la Croix and Fabre (2019), there is a discussion in Méchin (1890) and in Belin (1905) about one of the first rectors of the Royal Bourbon College, before the arrival of the Jesuits in 1621: Jean Hansenius. An assumption proposed by Méchin is that he may have been Cornelius Jansen (Jansenius). A student in Leuven in theology, Jansenius went to France for twelve years (1604-1616). He accompanied Duvergier de Hauranne, whom he met in Paris, to the South of France. In 1612, he became the rector of the College of Bayonne (South of France), and could have been at the Royal Bourbon College before or after that time. He came back to Leuven in 1616, was ordained, and became a professor there. His famous work on St. Augustine was later promoted by the Jansenists (including Port-Royal and Pascal, in 1656-7), and hated by the Jesuits, including those at the Royal Bourbon College.

Pierre Coton or Cotton (Nérende 1564 - Paris 1626). When the Royal Bourbon College was created, the Jesuits did not manage to rule it from the outset. However, some of them came regularly to Aix to preach, such as Pierre Coton in 1604 (the future confessor of Henry IV). He made a great impression, according to Méchin (1890), which enhanced the reputation of the Jesuits in the city, and would have contributed to their arrival. 


\section{AnECDOTES}

In July 1629, the plague broke out in Aix-en-Provence. Most notables fled the city and the students had already been leaving (end of the academic year). More than 11,000 people left the city in the first days, but some Jesuit fathers stayed, trying to implement non-pharmaceutical measures, such as affixing parchment to the latticed openings of confessionals to avoid airborne transmission, celebrating mass in the streets for the faithful to listen to from their windows,.... Others, like Paul du Barry, left Aix, and after a quarantine period, started preaching nearby. Among the members of the College who stayed in the city to help, at least eight Jesuits died. (Note written during the Covid-19 period).

Like many Jesuit colleges, the Royal Bourbon College would organize huge celebrations in the city to promote the order. In 1622 for instance, for the canonization of Saint Ignatius of Loyola, the founder of the Society of Jesus, and of Saint Francis Xavier, a parade was organized with fireworks. Banners hung for five years in the cathedral. Parades with professors and students, or quadrilles, were organized to celebrate the King of France (Louis XIII and Louis XIV). At the beginning of each academic year, the professors would read poetry of their own, celebrating olive trees, Provence, fig trees, ... or have their plays performed in French in front of a large audience.

\section{ApPENDIX}

The individual human capital index $q_{i}$ of an individual $i$ is given by:

$$
\begin{aligned}
q_{i}= & -1.76+0.43 \ln (\mathrm{nb} . \text { of characters of the longest Wikipedia page }) \\
& +0.40 \ln (\mathrm{nb} . \text { of Wikipedia pages in different languages })+0.47 \ln (\mathrm{nb} . \text { of works in Worldcat }) \\
& +0.46 \ln (\mathrm{nb} . \text { of publication languages in Worldcat }) \\
& +0.47 \ln (\mathrm{nb} . \text { of library holdings in Worldcat })
\end{aligned}
$$

We assume that having no Wikipedia page is similar to having one page with a length of 60 characters and that having no Worldcat page is similar to having a page with one work in one language held by one library. The constant -1.76 normalizes $q_{i}$ at 0 when there is neither a Wikipedia page, nor a Worldcat page. The weights $(0.43,0.40$, etc) are obtained from the first principal component of the five indicators (De la Croix et al. 2020).

The notability $Q$ of a university aggregates the $q$ of the top 5 individuals who were active in the preceding 25 years using the following formula:

$$
Q=\sqrt{\sum_{i=1}^{5} \frac{1}{5}\left(\frac{q_{i}}{s_{i}}\right)^{2}}
$$

where $s_{i}$ is the number of universities at which $i$ had an appointment.

\section{AcKNowledgments}

This project has received funding from the European Research Council (ERC) under the European Union's Horizon 2020 research and innovation programme, under grant agreement No 883033 "Did elite human capital trigger the rise of the West? Insights from a new database of European scholars.”

First version April 9, 2021. Updated November 26, 2021.

\section{REFERENCES}

Belin, Ferdinand. 1905. Histoire de l'ancienne université de Provence, ou Histoire de la fameuse univesité d'Aix: d'après les manuscrits et les documents originaux. Paris: A. Picard et fils. 
Callet, Albert. 1909. "Honoré Fabri de Virieu-le-Grand." Bulletin de la Société “Le Bugey” I:320-328.

De la Croix, David, Frédéric Docquier, Alice Fabre, and Robert Stelter. 2020. "The Academic Market and the Rise of Universities in Medieval and Early Modern Europe (1000-1800).” CEPR Discussion Paper 14509.

De la Croix, David, and Alice Fabre. 2019. “A la découverte des professeurs de l'ancienne université d'Aix, de ses origines á 1793." Annales du midi 131:379-402.

De la Croix, David, and Soraya Karioun. 2021. "Scholars and Literati at the University of Pont-àMousson (1572-1768).” Repertorium eruditorum totius Europae 2:1-6.

Frijhoff, Willem. 1996. "Patterns." Chapter 2 of A History of the University in Europe. Vol. II: Universities in Early Modern Europe (1500-1800), edited by Hilde de Ridder-Symoens. Cambridge University Press.

Masson, Paul R. 1931. Les Bouches-du-Rhône: encyclopédie départementale, Dictionnaire biographique des origines à 1800. Marseille: Archives départementales des Bouches-du-Rhône.

Méchin, Édouard. 1890. L’Enseignement en Provence avant la Révolution. Marseille: J. Evesque.

Sommervogel, Carlos. 1890. Bibliothèque de la Compagnie de fésus. Brussels: Oscar Schepens. 